\title{
Model Perhitungan Biaya Produksi Islami Menggunakan Metode Variable Costing (Studi Kasus Usaha Susu Shi Jeckex Cabang Jogja)
}

\author{
Ni'ma Khoirunnisa $^{1}$ \\ Siti Achiria ${ }^{2}$ \\ Universitas Islam Indonesia Yogyakarta \\ nimakhoirunnisa@gmail.com
}

\begin{abstract}
Every company is required to run its business very well. The success of a company is very much determined by the accuracy and ability of the leader in managing the company. Production costs are one part of the internal steps that must be taken in increasing efficiency. In Islam there is a classification of costs before calculating production costs because not all funds that come out are calculated as production costs. The company can exercise control over activities that do not add value, which refers to cost control to be effective by applying Variable Coasting methods. Because it is seen from the method of calculation, the variable costing approach is more practical and easy to analyze. The results show that, using a calculation with a variable costing approach, the total production costs are lower than the calculation of real use, which is Rp. 55. 718,000 while using the real calculation, the results are greater, which is $\mathrm{Rp}$. It can be seen that the calculation of the company's real production costs is higher than the calculation of production costs using the variable costing method. There is also the main difference between the real calculation of the company and the calculation of variable costing which is located in the treatment of factory overhead costs. The company's real calculations use fixed factory overhead and variable calculations while the variable costing method only calculates variable overhead costs.
\end{abstract}

\section{Keywords: Cost, Productions Cost, Variable Costing}

\begin{abstract}
Abstrak
Setiap perusahaan dituntut untuk bisa menjalankan usahanya dengan sangat baik. Keberhasilan suatu perusahaan sangat ditentukan dari kecermatan serta kemampuan pimpinan dalam pengelolaan perusahaan. Biaya produksi merupakan salah satu bagian dari langkah-langkah intern yang harus dilakukan dalam meningkatkan efisiensi. Dalam Islam terdapat pengklasifikaisan biaya sebelum menghitung biaya produksi karena tidak semua dana yang keluar dihitung sebagai biaya produksi. Perusahaan dapat melakukan pengendalian terhadap aktivitas-aktivitas yang tidak menambah nilai, dimana mengacu kepada pengendalian biaya agar efektif dengan menerapkan metode Variable Coasting. Karena dilihat dari cara perhitungannya, pendekatan variable costing lebih praktis dan mudah di analisis. Hasil penelitian menujukan bahwa, menggunakan perhitungan dengan pendekatan variable costing diperoleh total biaya produksi yang lebih rendah dibandingkan perhitungan menggunakan rill, yaitu $\mathrm{Rp} 55.718 .000$ sedangkan menggunakan perhitungan rill didapat hasil lebih besar yaitu Rp 67.568.000. Dapat dilihat bahwa perhitungan biaya produksi riil perusahaan lebih tinggi dibandingkan dengan perhitungan biaya produksi dengan menggunakan metode variable costing. Terdapat juga perbedaan utama antara perhitungan riil perusahaan dengan perhitungan variable costing yaitu terletak pada perlakuan biaya overhead pabrik. Perhitungan riil perusahaan menggunakan perhitungan biaya overhead pabrik tetap dan variable sedangkan metode variable costing hanya menghitung biaya overhead variabel saja.
\end{abstract}

Kata Kunci: Biaya, Biaya Produksi, Variable costing. 


\section{PENDAHULUAN}

Perkembangan zaman yang semakin modern dan keaadan di masyarakat saat ini bisa dilihat melalui kenaikan harga dan kurang stabilnya harga-harga bahan pokok khususnya dibagian pangan. Hal ini juga mengakibatkan timbulnya persaingan antar pengusaha. Setiap pengusaha maupun perusahaan dituntut untuk bisa menjalankan usahanya dengan sangat baik. Keberhasilan suatu perusahaan sangat ditentukan dari kecermatan serta kemampuan pimpinan dalam pengelolaan perusahaan. Pemilik perusahaan dituntut untuk menghasilkan produk yang bermutu tinggi dengan harga jual yang kompetitif untuk mencapai persaingan di dalam usaha. Salah satu unsur yang harus di perhatikan adalah bagaimana pimpinan memperhatikan dan menganalisis biaya produksi. Biaya produksi merupakan salah satu bagian dari langkah-langkah intern yang harus dilakukan dalam meningkatkan efisiensi. Pengendalian biaya diselaraskan dengan tujuan perusahaan salah satunya untuk memperoleh laba yang maksimal yaitu dengan mengeluarkan biaya yang serendah-rendahnya, maka dengan mengendalikan biaya produksi perusahaan berharap akan memperoleh laba yang besar.

Biaya produksi adalah sejumlah pengorbanan ekonomis yang harus dikorbankan untuk memproduksi suatu barang. Biaya produksi juga merupakan biaya yang digunakan dalam mengubah bahan baku menjadi barang jadi. Dalam Biaya produksi biasanya terdiri dari tiga unsur yaitu bahan baku langsung, tenaga kerja langsung dan overhead pabrik. Dimana bahan baku langsung adalah semua bahan baku yang membentuk bagian integral dan produk jadi dan dimasukkan secara ekspilit dalam perhitungan biaya produk. Tenaga kerja langsung adalah tenaga kerja yang melakukan konversi bahan baku langsung menjadi produk jadi dan dapat dibebankan secara layak ke produk tertentu, sedangkan overhead pabrik merupakan semua biaya manufaktur yang tidak ditelusuri secara langsung ke output tertentu.

Dalam Islam tisak semua pengeluaran dalam usaha dikatakan sebagai biaya namun ada beberapa pengeluaran (harta) yang memang harus kita keluarkan sebagai muslim untuk diberikan kepada yang membutuhkan, selain itu terdapat beberapa pengklasifikasian biaya Islami yang tidak termasuk dalam perhitungan biaya produksi.

Oleh karena itu bagi pengusaha kuliner, biaya produksi merupakan faktor penting untuk melihat berhasil atau tidaknya perusahaan jika ditinjau dari segi finansial. Pada usaha Susu Shi Jeckex cabang Jogja, biaya produksinya kurang dihitung secara terperinci serta pencatatan yang belum efektif.

Setiap usaha dapat melakukan pengendalian terhadap aktivitas-aktivitas yang tidak menambah nilai, dimana mengacu kepada pengendalian biaya agar efektif dengan menerapkan metode Variable Coasting. Karena dilihat dari cara perhitungannya, pendekatan variable costing lebih praktis dan mudah di analisis.

Christy Oentoe (2013) dalam penelitiannya menyatakan berdasarkan perhitungan metode variable costing yang telah dibuatnya, didapatkan hasil yang berbeda dengan perhitungan yang dibuat oleh perusahaan. Menggunakan perhitungan dengan pendekatan variable costing diperoleh total biaya produksi yang lebih rendah dibandingkan perhitungan yang dilakukan oleh perusahaan, yaitu Rp. 836.017.116 dengan menggunakan perhitungan variable costing dan Rp. 786.265.200 dengan menggunaka perhitungan riil yang dibuat oleh perusahaan. Perbedaan utama antara perhitungan riil perusahaan dengan perhitungan variable costing yaitu terletak pada perlakuan biaya overhead pabrik. Perhitungan riil perusahaan menggunakan perhitungan biaya overhead pabrik tetap dan variable sedangkan metode variable costing hanya menghitung biaya overhead variabel saja.

Calvin Readel Fredrik Worotitjan dan Jenny Morassa (2016) dalam penelitiannya menghitung biaya produksi, berdasarkan perhitungan dengan menggunakan metode activity based costing dan metode variable costing yang telah dibuat penulis, metode activity based costing didapat hasil yang lebih tinggi dibandingkan perhitungan biaya produksi menggunakan variable costing. Disamping itu, keunggulan dalam perhitungan variable costing 
adalah sebagai alat perencanaan jangka pendek dalam pengambilan keputusan. Sedangkan pada sistem activity based costing sebagai alat penetapan mark up yang tepat dan sebagai alat penetapan harga jual produk yang tepat.

Maka tujuan dari penelitian ini yaitu meganalisis model perhitungan biaya produksi dengan menggunakan pendekatan Variable costing ditinjau dari pengklasifikasian biaya Islami pada usaha Susu Shi Jeckex cabang jogja.

\section{TINJAUAN PUSTAKA Akuntansi}

Akuntansi adalah menyangkut angkaangka yang akan dijadikan dasar dalam proses pengambilan keputusan, angka itu menyangkut uang atau nilai moneter yang menggambarkan catatan dari transaksi perusahaan (Harahap, 2011, p. 5). Soemarso (2009) menyatakan Akuntansi (accounting) adalah suatu disiplin yang menyediakan informasi penting sehingga memungkinkan adanya pelaksanaan dan penilaian jalannya perusahaan secara efisien.

Horngren, Harrison dan Bamber (2006) menyatakan bahwa akuntansi adalah sistem informasi yang mengukur aktifitas bisnis, memproses informasi menjadi laporan keuangan, dan mengkomunikasikan hasilnya kepada para pembuat keputusan. Akuntansi merupakan 'bahasa bisnis'.

\section{Akuntansi Manajemen}

Krismiaji dan Aryani (2011) menyatakan bahwa akuntansi manajemen adalah suatu cabang ilmu akuntansi yang menghasilkan informasi untuk manajemen atau pihak intern perusahaan. Pengguna utama informasi akuntansi manajemen adalah para manajer yang bertugas merencanakan kegiatan, menerapkan rencana, dan mengarahkan serta mengendalikan kegiatan organisasi tersebut atau berjalan sesuai rencana. Informasi yang dihasilkan oleh akuntansi manajemen akan dimanfaatkan oleh para manajer untuk membantu melaksanakan tugasnya.

\section{Akuntansi Biaya.}

Akuntansi biaya adalah proses pencatatan, penggolongan, peringkasan, dan penyajian biaya-biaya pembuatan dan penjualan produk atau penyerahan jasa dengan cara-cara tertentu beserta penafsiran terhadap hasilnya. (Surjadi \& Lukman, 2013). Akuntansi biaya merupakan bagian dari akuntansi keuangan apabila akuntansi biaya ini berperan dalam memperhitungkan harga pokok produksi atau jasa yang dihasilkan dan sebagai bagian akuntansi manajemen ketika akuntansi biaya ini digunakan sebagai alat perencanaan, pengendalian dan pembuatan keputusan terhadap pemakaian biaya. Akuntansi biaya melengkapi manajemen dengan alat-alat yang diperlakukan untuk aktivitas-aktivitas perencanaan dan pengendalian, memperbaiki kualitas dan efisiensi, serta membuat keputusan-keputusan yang bersifat rutin maupun strategis. Akuntansi biaya mengukur dan melaporkan setiap informasi keuangan dan non keuangan yang terkait dengan biaya perolehan atau pemanfaatan sumber daya dalam suatu organisasi.

Hansen dan Mowen (2007) mengatakan bahwa akuntansi biaya menyediakan informasi yang dibutuhkan untuk akuntansi manajemen dan akuntansi keuangan. Akuntansi biaya memasukkan bagian-bagian akuntansi manajemen dan akuntansi keuangan tentang bagaimana informasi biaya dikumpulkan dan dianalisis.Akuntansi biaya adalah salah satu cabang akuntansi yang merupakan alat bagaimana manajemen untuk memonitor dan merekam transaksi biaya secara sistematis, serta menyajikan informasi biaya dalam bentuk laporan biaya. Manfaat biaya adalah menyediakan salah satu informasi yang diperlukan oleh manajemen dalam mengelola perusahaannya, yaitu untuk perencanaan dan pengendalian laba; penentuan harga pokok produk dan jasa serta bagi pengambilan keputusan oleh manajemen. Carter (2009) akuntansi biaya adalah perhitungan dengan tujuan untuk aktivitas perencanaan dan pengendalian perbaikan kualitas efisiensi, serta pembuatan keputusan yang bersifat rutin dan strategis.

\section{Biaya}

Menurut Sudarsono (1995) biaya dalam pengertian ekonomi adalah semua beban yang harus ditanggung untuk menyediakan barang agar siap dipakai konsumen. Jadi dari keterangan di atas dapat disimpulkan 
bahwa analisis biaya adalah suatu teknik yang digunakan untuk membandingkan berbagai biaya yang terkait dengan investasi dan manfaat yang ingin di dapatkan.

Supriyono (2011) menyatakan bahwa biaya adalah harga perolehan yang dikorbankan atau digunakan dalam rangka memperoleh penghasilan (revenues) dan akan dipakai sebagai pengulang penghasilan. Biaya digolongkan kedalam harga pokok penjualan, biaya penjualan, biaya administrasi dan umum, biaya bunga dan pajak perseroan. Garrison, et al (2008, p. 69) menyatakan bahwa biaya adalah beban yang sangat penting dalaam pembuatan keputusan. Dalam pembuatan keputusan, sangat penting untuk memiliki pemahaman yang kuat mengenai konsep biaya diferensial (differential cost), biaya kesempatan (opportunity cost) dan biaya tertanam (sunk cost).

\section{Biaya Produksi}

Menurut Soeharno (2007) yang dimaksud biaya produksi yaitu semua pengeluaran yang digunakan dalam proses produksi untuk menghasilkan barang atau jasa. Menurut Sadono Sukirno, yang dimaksud dengan biaya produksi yaitu semua pengeluaran yang dilakukan oleh perusahaan untuk memperoleh faktor-faktor produksi dan bahan-bahan mentah yang akan digunakan untuk menciptakan barang-barang yang diproduksikan perusahaan tersebut.

Pada umumnya biaya produksi meliputi:

1. Biaya bahan baku.

Merupakan bahan secara langsung digunakan dalam produksi untuk mewujudkan suatu macam produk jadi siap untuk dipasarkan.

2. Biaya tenaga kerja langsung dan tidak langsung.

Merupakan biaya-biaya bagi para tenaga kerja langsung yang ditempatkan dan didayagunakan dalam menangani kegiatankegiatan proses produk jadi yang secara langsung diterjunkan dalam kegiatan produksi.

3. Biaya overhead Pabrik.

Merupakan biaya dari bahan tidak langsung, tenaga kerja tidak langsung dan semua biaya pabrikasi lainnya yang tidak dapat dibebankan langsung kepada produk tertentu
Mulyadi (2010) menyatakan bahwa biaya produksi merupakan biaya-biaya yang dikeluarkan dalam pengelolahan bahan baku menjadi produk. Biaya produksi membentuk kos produksi, yang digunakan untuk menghitung kos produk jadi dan kos produk yang pada akhir periode akuntansi masih dalam proses. Mulyadi menyatakan bahwa penentuan kos produksi dipengaruhi oleh pendekatan yang digunakan untuk menentukan unsur-unsur biaya produksi yang diperhitungkan dalam kos produksi. Dalam metode variable costing, biaya produksi yang diperhitungkan dalam penentuan kos produksi adalah hanya terdiri dari biaya produksi variabel, yaitu biaya bahan baku, biaya tenaga kerja langsung dan overhead pabrik variabel.

\section{Variable costing}

Mulyadi (2010) menyatakan bahwa variable costing merupakan metode penentuan kos produksi yang hanya memperhitungkan biaya produksi yang berperilaku variable kedalam kos produksi, yang terdiri dari biaya bahan baku, biaya tenaga kerja langsung, dan biaya overhead pabrik variable. Variable costing adalah metode penentuan harga pokok produksi yang hanya membebankan biayabiaya produksi variabel saja ke dalam harga pokok produk.

Metode variable costing ini dikenal dengan nama direct costing. Istilah ini sebenarnya tidak berhubungan dengan cost (biaya langsung). Dalam metode variable costing, biaya overhead pabrik tetap diperlakukan sebagai unsur harga pokok produk, sehinhgga biaya overhead pabrik tetap dibebankan sebagai biaya dalam periode terjadinya. Dengan demikian biaya overhead pabrik tetap didalam metode variable costing tidak melekat pada persediaan produk yang belum laku dijual, tetapi langsung dianggap sebagai biaya dalam periode terjadinya.

Witjaksono (2006) menyatakan bahwa metode variable costing banyak diterapkan bagi keperluan pelaporan internal, karena metode ini dianggap konsisten dengan asumsi perilaku biaya yang kerap digunakan dalam pengambilan keputusan manajemen. Perlu diketahui bahwa variable costing ini memiliki beberapa kelebihan yang perlu diketahui, diantaranya: 
a. Membantu dalam mengendalikan biaya Dengan menggunakan variable costing ini manajemen usaha dapat memisahkan biaya tetap dari laporan laba rugi sehingga pihak manajemen bisa focus pada perilaku biaya tetap ini.

b. Membantu pengambila keputusan jangka panjang

Dengan menggunakan variable costing ini pihak manajemen usaha bisa menentukan pengambilan keputusan, misalnya jika ada pesanan khusus maka harga produknya sudah bisa ditentukan diawal lewat variable costing.

c. Membantu perencanaan penentuan laba jangka pendek

Pihak pengelola usaha atau manajemen memerlukan informasi mengenai biaya yang sudah dipisahkan menurut perilaku dan menurut volume perubahan produksi untuk menentukan laba dalam jangka pendek.

\section{Pencatatan Akuntansi Islami}

Akuntansi yang merupakan cabang ilmu ekonomi yang saat ini sangat pesat perkembangannya disemua sektor baik swasta maupun publik, ternyata konsep dasarnya telah diperkenalkan oleh Al-Quran, hal ini dapat dilihat berdasarkan Surat Al-Baqarah ayat 282 .

Artinya "Wahai orang-orang yang beriman! Apabila kamu melakukan utang piutang untuk waktu yang ditentukan, hendaklah kamu menuliskannya. Dan hendaklah seorang penulis di antara kamu menuliskannya dengan benar. Janganlah penulis menolak untuk menuliskannya sebagaimana Allah telah mengajarkan kepadanya, maka hendaklah dia menuliskan..."

Dengan kata lain, Islam menganggap bahwa transaksi ekonomi (muamalah) memiliki nilai urgensi yang sangat tinggi, sehingga adanya pencatatan dapat dijadikan sebagai alat bukti (hitam di atas putih), menggunakan saksi (untuk transaksi yang material) sangat diperlukan karena dikhawatirkan pihakpihak tertentu mengingkari perjanjian yang telah dibuat. Untuk itulah pembukuan yang disertai penjelasan dan persaksian terhadap semua aktivitas ekonomi keuangan harus berdasarkan surat-surat bukti berupa: faktur, nota, bon kuitansi atau akta notaris untuk menghindari perselisihan antara kedua belah pihak. Kemudian adanya sistem pelaporan yang komprehensif akan memantapkan manajemen karena semua transaksi dapat dikelola dengan baik sehingga terhindar dari kebocoran.

Prinsip akuntansi syariah menurut Muhammad (2002) terbagi dalam dua bagian utama, yaitu: 1 . berdasarkan pengukuran dan penyingkapan dan 2 . berdasarkan pemegang kuasa dan pelaksana. Prinsip akuntansi syari'ah berdasarkan pengukuran dan penyingkapannya terdiri dari, pertama zakat, kedua bebas bunga dan ketiga halal. Sedangkan Prinsip akuntansi syari'ah berdasarkan pemegang kuasa dan pelaksana yaitu:

1. Prinsip pertanggung jawaban (accountability), senantiasa berkaitan dengan konsep amanah. Bagi kaum muslim, persoalan amanah merupakan hasil transaksi manusia dengan sang khalik, sebagaimana Allah berfirman dalam surat (At Thalaaq ,Q.S 65:8)

Artinya "Dan berapalah banyaknya (penduduk) negeri yang mendurhakai perintah Tuhan mereka dan Rasul-rasulnya, maka kami hisab penduduk negeri itu dengan hisab yang keras, dan kami azab mereka dengan azab yang mengerikan" (QS. At Thalaaq:8)

2. Prinsip keadilan dalam melakukan transaksi. Prinsip keadilan ini tidak saja merupakan nilai penting dalam etika kehidupan sosial dan bisnis, tetapi juga merupakan nilai inheren yang melekat dalam fitrah manusia.

3. Prinsip kebenaran, prinsip ini sebenarnya tidak dapat dilepaskan dengan prinsip keadilan. Karena dalam akuntansi kita senantiasa dihadapkan pada masalah pengakuan dan pengukuran.

\section{Hubungan Variable Costing Dengan Pengklasifikasian Biaya Islami}

Berikut adalah aktivitas atau item-item yang dapat digolongkan menjadi objek biaya, yaitu (Elwardi, 2014):

\section{Klasifikasi Biaya}

Dalam Islam harus ada kejelasan dalam setiap aktivitasnya, tidak boleh ada unsur yang 
samar (gharar), maksudnya semua jual beliyang mengandung ketidakjelasan seperti pertaruhan atau perjudian karena tidak dapat dipastikan jumlah dan ukurannya, atau tidak mungkin diserah terimakan (Ghufran, 2002) sehingga penetapan biaya harus dilakukan per aktivitas. Misalnya aktivitas A perhitungan biayanya dirinci sesuai dengan biaya yang benar-benar dikeluarkan untuk aktivitas tersebut. Sehingga nantinya aka nada biaya tetap aktivitas A biaya variable aktivitas A. Kemudian yang menjadi persoalan adalah sulitnya untuk menentukan secara tepat berapa biaya tetap yang benarbenar terpakai untuk suatu aktivitas. Dalam hal ini tentunya kita berupaya seakurat mungkin untuk menentukan besaran dari biaya produksi menggunakan metode Variable costing. Metode ini bermanfaat untuk menentukan harga jual dalam jangka pendek.

\section{Sistem perhitungan biaya.}

Dalam akuntansi Islam lebih ditekankan darimana sumber pembiayaan atau modal proses produksi barang atau jasa tersebut. Produksi suatu barang harus qath'i (jelas) biayanya. Yang menjadi perhatian dalam Akuntansi Islami disini adalah tentang modal, apakah yang digunakan berasal dari hutang, baik itu hutang jangka pendek maupun hutang jangka panjang. Islam tidak melarang hutang tetapi juga tidak menganjurkannya. Rasulullah pernah tidak mau menshalatkan seseorang karena orang tersebut meninggal dunia dalam keadaan masih memiliki utang. Sehingga sedapat mungkin dihindari berhutang. Apalagi jika utang tersebut mengandung unsur riba. Rasulullah shallallahu 'alaihi wa sallam melaknat orang yang memakan riba, memberi riba, juru tulisnya dan dua saksinya, apakah itu riba nasiah maupun riba fadhl. Beliau mengatakan: 'Mereka itu sama'.

Sehingga sebisa mungkin menghidari hutang apalagi jika hutang itu mengandung unsur riba. Tidak boleh menggunakan hutang yang mengandung unsur riba untuk aktivitas perusahaan. Bagaimana jika sebagian aktivitas perusahaan terlanjur dijalankan dari hutang?, maka dari itu harus dijelaskan secara rinci berapa jumlahnya dan digunakan dimana serta digunakan untuk biaya apa. Kemudian hasilnya nanti dibagi sesuai proporsi pembiayaan dari hutang maupun pembiayaan dari pemilik modal. Kemudian proporsi hasil yang berasal dari hutang harus dipisahkan dari laba perusahaan yang dibagi pada para pemilik modal. Laba dari hutang ini sebaiknya disumbangkan untuk kegiatan social maupun kegiatan keagamaan.

\section{Jenis biaya yang tidak dapat diakui.}

Pada akuntansi konvensional segala bentuk pengeluaran atau pengorbanan ekonomi yang berhubungan dengan aktivitas perusahaan, baik yang berhubungan langsung maupun tidak langsung dapat diakui sebagai biaya. Dalam akuntansi Islam, tidak setiap pengeluaran bisa dianggap sebagai biaya. Pengeluaran yang tidak sesuai dengan syariat Islam tidak dapat diakui sebagai biayaa, seperti:

\section{Pembelian barang haram}

Islam melarang jual beli barang-barang yang haram. Transaksi yang tidak sesuai dengan ketentuan syariah, harus dihindari, sebab setiap aktivitas usaha harus dinilai halal-haramnya. Faktor ekonomi bukan alasan tunggal untuk menentukan berlangsungnya kegiatan usaha. Misalkan perusahaan membeli alkohol untuk suatu keperluan. Pengeluaran yang dikeluarkan untuk mendapatkan alkohol itu tidak dapat dianggap sebagai biaya tetapi dianggap sebagai rugi karena Islam melarang pemanfaatan alkohol meskipun tidak diminum. Rasulullah dulu memerintahkan para sahabatnya agar membuang/menumpahkan khamar (minuman beralkohol). Para sahabat protes dengan alasan khamar ini tidak diminum dan hanya digunakan untuk hal lain. Akan tetapi Rasulullah tetap memerintahkan untuk membuangnya. Dari kisah ini dapat disimpulkan larangan membeli, menjual, memanfaatkan sesuatu yang haram. Pelakunya mendapatkan dosa dan kerugian di dunia maupun akhirat.

\section{Asuransi}

Hai' ah Kibaril Ulama (Majelis Ulama Besar) dan Majma' Al-Fiqh Al-Islami (Dewan Fiqh Internasional) menetapkan haramnya seluruh jenis asuransi yang berjalan dengan sistem perdagangan, baik itu asuransi jiwa, 
barang, atau yang lainnya karena mengandung unsur untung-untungan atau judi. Bagaimana jika asuransi ini diwajibkan pemerintah atau perusahaan terlanjur membayar premi asuransi? Jika mendapatkan klaim perusahaan hanya boleh mengambil pokok asuransi yang dibayarkannya sisa lebihnya diinfakkan untuk umat. Sementara jika tidak mendapatkan klaim, pengeluaran yang dibayarkan pada perusahaan asuransi dianggap sebagai kerugian.

\section{Biaya Suap}

Risywah (Suap) dalam Islam diharamkan. Rasulullah melaknat orang yang memberi suap maupun orang yang menerima suap. Pengeluaran yang dikeluarkan tidak dapat diakui sebagai biaya tetapi dianggap sebagai kerugian. Hal ini tidak berlaku jika perusahaan melakukan suap karena terpaksa, jika tidak menyuap maka perusahaan tidak mendapatkan haknya. Pengeluaran ini dapat dianggap sebagai biaya.

Infaq, sedekah dan Wakaf

Dalam konsep Islam segala pengorbanan kita baik itu berupa materiil maupun non materiil bukanlah sebagai biaya. Akan tetapi dianggap sebagai investasi. Allah berfirman dalam QS Surat Al Baqarah ayat 261.

Artinya:" perumpamaan (nafkah yang dikeluarkan oleh) orang-orang yang menafkahkan hartanya di jalan Allah adalah serupa dengan sebutir benih yang menumbuhkan tujuh bulir, pada tiap-tiap bulir seratus biji. Allah melipat gandakan (ganjaran) bagi siapa yang Dia kehendaki. dan Allah Maha Luas (karunia-Nya) lagi Maha mengetahui". (QS Al-Baqarah.2:261)

Dari ayat ini dapat disimpulkan pengeluaran yang dilakukan di jalan Allah kelak akan mendapatkan gantinya sebesar 700 kali lipat. Infaq atau sedekah merupakan donasi sukarela.

\section{Pembayaran bunga bank}

Sudah sangat jelas bahwa bunga bank termasuk riba yang haram. Oleh karena itu tidak dapat dianggap sebagai biaya tetapi sebagai kerugian.

\section{Zakat}

Pembayaran zakat tidaklah dapat dianggap sebagai biaya karena pada hakikatnya harta yang dizakatkan itu bukanlah milik perusahaan tetapi milik orang-orang yang berhak dizakati baik itu fakir miskin dan lainnya. Oleh karena itu dalam membayar zakat tidak dihitung sebagai biaya tetapi dihitung sebagai pengembalian asset milik orang lain. Zakat adalah harta yang wajib dikeluarkan oleh muzakki sesuai dengan ketentuan syariah untuk diberikan kepada yang berhak menerimanya (Mustahiq).

Aktivitas yang bertentangan dengan syariat Islam.

Segala macam tindakan yang tidak dibenarkan oleh Islam yang dilakukan perusahaan tidak dapat dianggap sebagai biaya tetapi dianggap sebagai kerugian.

Dari pemaparan diatas, dapat kita pahami bahwa seluruh pengeluaran atau dana yang keluar dari hasil usaha tidak sepenuhnya bisa dihitung sebagai biaya, karena dalam Islam ada aturan-aturan yang harus dipenuhi, ada kewajiban yang harus kita tunaikan dan ada batasan-batasan dalam mengelola biaya dalam usaha.

\section{METODE PENELITIAN}

\section{Jenis Penelitian}

Metode yang digunakan dalam penelitian ini adalah metode deskriptif dengan mengunakan pedekatan kualitatif. Penelitian ini dilakukan untuk membuat suatu uraian sistematis berdasarkan pengumpulan data-data seperti sejarah perusahaan, struktur organisasi, job description, visi dan misi perusahaan, produksi perusahaan.

\section{Teknik Pengumpulan Data}

Dalam proses penelitian dan penulisan artikel ini, penulis menggunakan teknik pengumpulan data adalah sebagai berikut:

Wawancara yaitu, suatu teknik pengumpulan data dengan melaksanakan tanya jawab langsung mengenai topik kepada pegawai yang mempunyai wewenang untuk memberikan data dan informasi yang diperlukan dalam penulisan.

Observasi yaitu, teknik pengumpulan data dengan mengadakan pengamatan secara langsung atau seksama pada pelaksanaan 
usaha dalam hal ini Susu Shi Jeckex cabang Jogja.

Studi kepustakaan yaitu, suatu teknik pengumpulan data dengan cara membaca buku-buku, referensi dan literatur yang berhubungan dengan penyusunan laporan akhir.

Dokumentasi adalah, cara pengumpulan data melalui peninggalan tertulis terutama berupa arsip-arsip dan termasuk juga bukubuku mengenai pendapat, teori, hukumhukum, dan lain-lain yang berhubungan dengan masalah penelitian

\section{Analisis Data}

Metode analisis data yang digunakan dalam penelitian ini yaitu metode deskriptif kualitatif, yaitu suatu metode pembahasan permasalahan yang sifatnya menguraikan, menggambarkan, membandingkan suatu data atau keadaan, serta menuliskan dan menerangkan suatu keadaan sedemikian rupa sehingga bisa menarik kesimpulan.Untuk teknik analsisis data adalah sebagai berikut:

1. Melakukan observasi ke perusahaan untuk mencari tahu metode perhitungan apa yang digunakan perusahaan dalam menentukan biaya produksi.

2. Mengambil data biaya-biaya dari perusahaan.

3. Perhitungan biaya-biaya berdasarkan metode variable costing yang ada dalam Tinjauan Pustaka.

\section{HASIL DAN PEMBAHASAN \\ Gambaran Umum Usaha}

Susu Shi Jeckex merupakan jenis usaha di bidang kuliner minuman susu murni yang banyak diminati mulai dari remaja hingga orang tua. Susu Shi Jeckex pertama lahir di Solo pada tahun 1986 dan menjadi salah satu destinasi kuliner di Solo, hingga saat ini sudah memiliki 20 cabang di daerah Solo, kemudian pada tahun 2014 membuka cabang di Jogja dan menjadi satu-satunya cabang di daerah Jogja, yang beralamatkan di jalan kaliurang $\mathrm{km} \mathrm{8,5}$ Sleman, Daerah Istimewa Yogyakarta (Teguh, Sejarah Usaha, 2019). Letaknya sangat strategis karena tepat berada dipinggir jalan raya kaliurang. Jenis usaha ini berbasis keluarga jadi seluruh cabang dari Susu Shi Jeck adalah milik seluruh keluarga dan seluruh pekerja pun dianggap sebagai keluarga itu sebabnya tidak adanya tingkatan jabatan ataupun perbedaan gaji pekerja. Dalam penelitian ini menggunakan model variable costing terdapat biaya-biaya yang akan diteliti yaitu biaya bahan baku, biaya tenaga kerja langsung dan biaya overhead pabrik variable.

\section{Hasil Penelitian}

Dalam bisnis tentunya harus menghitung biaya-biaya yang dikeluarkan. Biaya-biaya yang ada dalam bisnis Susu Shi Jeckex terbagi atas tiga golongan besar, yaitu:

Tabel 1. Biaya bahan langsung dalam satu bulan.

\begin{tabular}{lllr}
\multicolumn{1}{c}{ Bahan Baku } & \multicolumn{1}{c}{ Harga } & \multicolumn{1}{c}{ Total Perbulan } & Total (dalam Rupiah) \\
\hline Susu Sapi & $8.000 /$ Liter & 3000 Liter & 24.000 .000 \\
\hline Gula Pasir & $12.000 / \mathrm{Kg}$ & $270 \mathrm{~kg}$ & 3.240 .000 \\
Coklat Bubuk & $24.500 /$ Box & $120 \mathrm{Box}$ & 2.940 .000 \\
Sirup Melon & $18.000 /$ Botol & $60 \mathrm{Botol}$ & 1.080 .000 \\
Sirup Mocca & $18.000 /$ Botol & 60 Botol & 1.080 .000 \\
Sirup Rose & $18.000 /$ Botol & 90 Botol & 1.620 .000 \\
Madu & $23.000 /$ Botol & 60 Botol & 1.380 .000 \\
Jahe Giling & $1.200 /$ ons & 9 Kg & 108.000 \\
Kopi Hitam & $5.000 /$ bungkus & 30 bungkus & 150.000 \\
Teh & $3.000 /$ bungkus & 60 bungkus & 180.000 \\
Soda Fanta & $2.500 /$ Botol & 120 Botol & 300.000 \\
Telur Ayam Kampung & $1.900 /$ Butir & 2.100 Butir & 3.990 .000 \\
\hline Total & & & 40.068 .000 \\
\hline
\end{tabular}

Sumber : Data penelitian yang diolah 


\section{Biaya Bahan Langsung}

Biaya bahan langsung untuk memproduksi susu dengan varian rasa tidak begitu banyak. Biaya bahan langsun terdiri atas: Susu sapi, gula, coklat, sirup melon, sirup, madu, kopi, teh, soda fanta, jahe. Berikut ini adalah harga dan pemakaian bahan langsung Susu Shi Jeckex dalam satu bulan.

Dalam pemilihan bahan baku, pemilik sudah memastikan langsung ke pemasok bahwa bahan baku tersebut halal dan baik dari segi pengolahan dan cara mendapatkannya (Teguh, 2019).

\section{Biaya Tenaga Kerja Langsung}

Menurut pemilik usaha Susu Shi Jeckex, upah langsung adalah jumlah keseluruhan upah yang diberikan kepada karyawan mulai dari pengelolaan bahan baku hingga menjadi bahan jadi. Besarnya tariff upah ditentukan menurut kebijakan pemilik usaha. Dengan jumlah tenaga kerja 6 orang.

Pada usaha Susu Shi Jeckex cabang Jogja terdapat 7 orang yang terlibat, yaitu seorang pemilik usaha, 3 orang di lapangan atau bagian penjualan dan 3 orang lainnya di rumah produksi sebagai pekerja untuk menyiapkan bahan-bahan yang akan dijual. Dimana seluruhnya termasuk tenaga kerja langsung, karena dalam usaha Susu Shi Jeckex ini lebih menekankan pada usaha keluarga, jadi itu sebabnya tidak ada tingkatan jabatan atau perbedaan upah. Upah untuk tenaga kerja langsung ini dihitung tiap harinya, dan upah perhari tenaga kerja langsung sebesar $\mathrm{Rp}$. 55.000 perorang (Teguh, 2019).

Untuk itu biaya tenaga kerja perbulan adalah: Upah perhari $x$ jumlah hari kerja dalam sebulan Rp $55.000 \times 27$ hari $=$ Rp. 1.500 .000
Jadi, untuk biaya tenaga kerja langsung perbulannya adalah:

6 orang $\times$ Rp $1.500 .000=$ Rp. 9.000 .000

Jadi upah tenaga kerja tidak langsung selama satu bulan adalah:

Biaya Berobat apabila sakit sebesar Rp 100.000 6 orang $x \operatorname{Rp} 100.000=\operatorname{Rp} 600.000$

\section{Biaya Overhead Pabrik}

Biaya overhead pabrik yang ada pada Usaha Susu Shi Jeckex adalah biaya-biaya bahan pembantu seperti plastik pembungkus, sedotan, kresek, biaya listrik, telepon, bahan bakar, air, gas, perlengkapan usaha, pemeliharaan Usaha.

Biaya overhead pabrik dalam satu bulan produksi adalah Rp 18.500.000.

Hal utama yang dibutuhkan dalam usaha adalah adanya modal, dalam hal ini Ibu Purwanti sebagai pemilik Usaha Susu Shi Jeckex dalam memulai usahanya berasal dari modal keluarga dan tabungannya sendiri, tidak adanya pinjaman dari bank atau pinjaman yang berbunga serta mengandung unsur riba.

Dalam biaya-biaya yang termasuk kedalam biaya overhead pabrik adalah biaya yang sebenar-benarnya maksudnya bukan pengeluaran yang dilarang dalam Islam untuk dilingkup dalam biaya. Misalnya seperti Zakat, Infaq yang dikeluarkan oleh pemilik untuk diberikan kepada lembaga ataupun diberikan langsung kepada orang yang membutuhkan tidak termasuk dalam biaya. Kemudian selain itu ada biaya asuransi bangunan (Ruko) yang dibebankan pemilik bangunan kepada penyewa dalam hal ini pemilik Usaha Susu Shi Jeckex.

Tabel 2. Biaya Overhead Pabrik Dalam Satu Bulan.

\begin{tabular}{|c|c|c|c|}
\hline Biaya OHP & Tetap & Variabel & Total \\
\hline Bahan tidak langsung. & & Rp 3.300.000 & $\operatorname{Rp} 3.300 .000$ \\
\hline Upah tenaga kerja tidak langsung & Rp 600.000 & & $\operatorname{Rp} 600.000$ \\
\hline Perlengkapan usaha & $\operatorname{Rp} 10.000 .000$ & & $\operatorname{Rp} 10.000 .000$ \\
\hline Listrik & & Rp 500.000 & $\operatorname{Rp} 500.000$ \\
\hline Sewa Ruko dan Air & $\operatorname{Rp} 1.250 .000$ & & $\operatorname{Rp} 1.250 .000$ \\
\hline Sabun Cuci & & Rp 150.000 & $\operatorname{Rp} 150.000$ \\
\hline Gas & & Rp 2.700 .000 & $\operatorname{Rp} 2.700 .000$ \\
\hline Total & Rp 11.850.000 & Rp 6.650.000 & $\operatorname{Rp} 18.500 .000$ \\
\hline
\end{tabular}

Sumber: Data penelitian yang di olah 


\section{Pembahasan}

Perhitungan Biaya Produksi Rill Perusahaan:

Pada usaha Susu Shi Jeckex perhitungan biaya produksi tidak dilakukan pencatatan atau perhitungan secara terperinci, menurut Ibu Purwanti selaku pemilik karena biaya yang dikeluarkan setiap harinya rata-rata sama, jadi tidak adanya pencatatan khusus. Berikut ini adalah penentuan harga biaya produksi berdasarkan perhitungan rill Usaha Susu Shi Jeckex.

\section{Perhitungan Rill Perusahaan}

Bahan langsung

Tenaga Kerja langsung

Overhead Pabrik Variabel

Overhead Pabrik Tetap

: Rp 40.068.000

: Rp 9.000.000

: Rp 6.650 .000

: Rp 11.850 .000

Rp 67.568.000

Perhitungan Biaya Produksi dengan menggunakan pendekatan variable costing:

Dalam menentukan biaya produksi yang ada dalam Usaha Susus Shi Jeckex hanya membebankan unsur-unsur biaya produksi yang bersifat variabel saja. Adapun unsurunsur biaya variabel itu adalah biaya bahan langsung, biaya upah langsung, dan biaya overhead variabel. Pemebebanan biaya produksi tersebut dilakukan berdasarkan biaya historis atau biaya yang sesungguhnya terjadi.

Berdasarkan teori yang ada, biaya variabel pabrik sebaiknya dibebankan berdasarkan tarif biaya overhead yang telah ada, karena tidak mungkin mengukur biaya overhead variabel dengan tepat yang harus di bebankan terhadap suatu produk. Selain itu, dengan menggunakan tarif biaya overhead yang telah ada, maka dapat disusun standar dan anggaran biaya untuk keperluan pengawasan dan efisiensi kerja. Pengalokasian biaya overhead menurut teori yang ada. Dari hasil analisa yang telah dilakukan maka berikut ini penulis akan menghitung harga pokok produksi dengan menggunakan variable costing.

\section{Variable costing}

Bahan langsung

: Rp 40.068.000

Tenaga Kerja langsung $\quad$ : Rp 9.000 .000

Overhead pabrik Variabel $\quad$ : Rp 6.650 .000

Total biaya produksi variable $\mathrm{Rp} 55.718 .000$
Jadi, perbedaan perhitungan antara perhitungan riil perusahaan dengan variable costing dapat terlihat jelas pada table berikut ini:

Tabel 3. Perbedaan perhitungan antara perhitungan riil perusahaan dengan variable costing.

\begin{tabular}{lll}
\hline \multicolumn{1}{c}{ Keterangan } & \multicolumn{1}{c}{$\begin{array}{c}\text { Rill } \\
\text { Perusahaan }\end{array}$} & $\begin{array}{c}\text { Variable } \\
\text { costing }\end{array}$ \\
\hline Bahan langsung & $\mathrm{Rp} 40.068 .000$ & $\mathrm{Rp} 40.068 .000$ \\
Tenaga kerja langsung & $\mathrm{Rp} 9.000 .000$ & $\mathrm{Rp} 9.000 .000$ \\
$\begin{array}{l}\text { Overhead pabrik } \\
\text { Variabel }\end{array}$ & $\mathrm{Rp} 6.650 .000$ & $\mathrm{Rp} 6.650 .000$ \\
Overhead pabrik tetap & $\mathrm{Rp} 11.850 .000$ & \\
\hline Total & $\mathbf{R p ~ 6 7 . 5 6 8 . 0 0 0}$ & $\mathbf{R p ~ 5 5 . 7 1 8 . 0 0 0}$ \\
\hline
\end{tabular}

Sumber: Data penelitian yang diolah

Perhitungan metode variabels costing didapatkan hasil yang berbeda dengan perhitungan perusahaan. Perhitungan dengan menggunakan riil perusahaan di dapatkan hasil per bulannya Rp 67.568.000 sedangkan menggunakan perhitungan variable costing di dapatkan hasil per bulannya Rp 55.718.000.

\section{KESIMPULAN}

Berdasarkan hasil penelitian maka dapat disimpulkan sebagai berikut

1. Berdasarkan perhitungan metode dengan menggunakan perhitungan rill dan metode variable costing yang telah dibuat oleh penulis, didapatkan hasil yang berbeda. Menggunakan perhitungan dengan pendekatan variable costing diperoleh total biaya produksi yang lebih rendah dibandingkan perhitungan rill, yaitu $\mathrm{Rp}$ 55. 718.000 sedangkan menggunakan perhitungan rill didapat hasil lebih besar yaitu Rp 67.568.000.

2. Terdapat perbedaan utama antara perhitungan riil perusahaan dengan perhitungan variable costing yaitu terletak pada perlakuan biaya overhead pabrik. Perhitungan riil perusahaan menggunakan perhitungan biaya overhead pabrik tetap dan variable sedangkan metode variable costing hanya menghitung biaya overhead variabel saja. Keuntungan dalam perhitungan variable costing adalah sebagai alat perencanaan jangka pendek dalam pengambilan keputusan. 
3. Dalam perhitungan variable costing, biaya yang diinput adalah biaya yang sebenar-benarnya maksudnya bukan pengeluaran yang tidak termasuk dalam pengklasifikasian biaya menurut Islam.

\section{DAFTAR PUSTAKA}

Carter, W. K. 2009. Akuntansi Biaya 1. Jakarta: Salemba Empat.

Elwardi, H. 2014. Cost Accounting dalam Perspektif Syariah. Jurnal Riset Akuntansi dan Bisnis, 188-214.

Garrison, Norren, \& Bewer. (2008). Akuntansi Manajeril. Jakarta: Edisi II. Buku 1. Salemba Empat.

Ghufran, A. M. 2002. Fiqih Muamalah Kontekstual. Jakarta: PT. Raja Grafindo Persada.

Hansen, D. R., \& Mowen, M. M. 2007. Managerial Accouting. In 8 th edition. Western Australia: Thomson South.

Harahap, S. H. 2011. Analisis Kritis Atas Laporan Keuangan. Jakarta: Raja Grafindo Persada.

Horngren, Harison, \& Bamber. 2006. Akuntansi. Klaten: PT. Intan Sejati.

Krismaji, \& Aryani A., Y. 2011. Akuntansi Manajemen. Yogyakarta: Unit Penerbit dan Percetakan Sekolah Tinggi Ilmu Manajemen YKPN.

Muhammad. 2002. Pengantar Akuntansi Syariah. Jakarta: Salemba Empat.
Mulyadi. 2010. Akuntansi Biaya. Yogyakarta: Unit Penerbit dan Percetakan Sekolah Tinggi Ilmu Manajemen YKPN.

Oentoe, C. (013. Analisis Perhitungan Biaya Produksi Menggunakan Variable Costing. Jurnal EMBA Vol. 1, No.3, 599605.

Soeharno. 2007. Ekonomi Manajerial. Yogyakarta: C.V Andi Offset.

Soemarsono. 2009. Akuntansi Suatu Pengantar. In Soemarsono, Akuntansi Suatu Pengantar. Jakarta: Salemba Empat.

Sudarsono. 1995. Pengantar Ekonomi Mikro. Jakarta: PT. Pustaka LP3ES Indonesia.

Supriyono, R. A. 2011. Akuntansi Biaya. Yogyakarta: BPFE.

Surjadi, \& Lukman. 2013. Akuntansi Biaya. Jakarta: Penerbit Indeks.

Teguh. 2019, Januari 17. Apakah ada tingkatan jabatan dan perbedaan gaji. (N. Khoirunnisa, Interviewer)

Teguh. 2019, Januari 17. Bagaimana dalam memilih bahan baku. (N. Khoirunnisa, Interviewer)

Teguh. (2019, Januari 217). Sejarah Usaha. (N. Khoirunnisa, Interviewer)

Witjaksono, A. (2006). Akuntansi Biaya. Yogyakarta: Graha Ilmu.

Worotitjan, C. R., \& Morassa, J. (2016). Analisis Perhitungan Biaya Produksi Pada PT. Manado Nusantara Informasi (Koran Sindo). Jurnal EMBA Vol. 4, No. 1, 974-981. 